\title{
Yaz Kamplarına Katılan Öğrencilerin Sportmenlik Davranışlarının ve Spora Katılım Güdülerinin Bazı Değişkenlere Göre İncelenmesi
}

\author{
Şeymanur BİRCAN ${ }^{*}$ iD, M. Çağrı ÇETİN ${ }^{10}$ \\ ${ }^{1}$ Mersin Üniversitesi, Spor Bilimleri Fakültesi.
}

Orijinal Makale

Gönderi Tarihi: 12.03.2021
Kabul Tarihi: 09.05.2021

DOI:10.30769/usbd.896100

Online Yayın Tarihi:30.06.2021

\section{$\ddot{O} z$}

Bu çalışmanın amacı yaz kamplarına katılan ortaokul ve lise öğrencilerinin sportmenlik davranışları ile spora katılım güdüleri arasındaki ilişkiyi istatiksel olarak tespit etmek bunun yanında cinsiyet, sınıf düzeyi, kardeș sayısı, anne-baba eğitim durumu değişkenleriyle karşılaştırmaktır. Çalı̧̧ma, gerekli izinler alınarak, 2018 yaz döneminde Ankara Büyükşehir Belediyesine bağlı Altınoluk Sosyal Tesisleri’ne kamp amaçlı gelen 208 genç kadın (\%53.2) ve 183 genç erkek (\%46.8) toplam 391 öğrencinin gönüllü olarak katılımıyla başlatılmıştır. Çalışmaya katılan öğrencilerin sportmenlik davranışlarını ölçmek amacıyla "Beden Eğitimi Dersi Sportmenlik Davranış1 Ölçeği”, spora katılım güdülerini ölçmek amacıyla ise "Spora Katılım Güdüsü Ölçeği”" kullanılmıştır. Ölçekler için yapılan güvenirlik testi sonucunda BEDSDÖ'nin nin Cronbach Alpha katsayısı .86, SKGÖ'nin ise .81 bulunmuştur. Öğrencilerin sportmenlik puanları cinsiyetle karşılaştırıldığında genç kadın öğrencilerin puanları genç erkek öğrencilere göre daha yüksek bulunmuştur, öğrencilerin sportmenlik puanları ile sınıf düzeyleri, anne-baba eğitim durumları ve kardeş sayısı değişkenleri arasında fark/ilişki bulunamamıştır. Öğrencilerin spora katılım güdüsü puanları ile cinsiyet, sınıf düzeyi, anne-baba eğitim durumu ve kardeş sayısı değişkenleri arasında fark/ilişki bulunmamıştır. Öğrencilerin sportmenlik puanları ile spora katılım güdüsü puanları arasında negatif yönde, düşük düzeyde, anlamlı bir ilişki saptanmıştır. Bu sonuca göre katılımcıların sportmenlik düzeyleri arttıkça spora katılım güdüleri azalmaktadır veya sportmenlik düzeyleri azaldıkça spora katılım güdüleri artmaktadır.

Anahtar kelimeler: Sportmenlik, Fair-play, spora katılım güdüsü, motivasyon.

\section{Investigation of the Sportpersonship Behaviors of the Student Participating I- in the Summer Camps and Their Participation Motivation as of Some Variables}

\begin{abstract}
The aim of this study is to statistically determine the relationship between the sportspersonship behaviors of middle and high school students attending summer camps and their motivations to participate in sports, as well as to compare it with the variables of gender, grade level, number of siblings, and parents' educational status. The study was initiated with the voluntarily participation of a total of 391 students, including 208 young women (53.2\%) and 183 young men (46.8\%), who came to Altınoluk Social Facilities affiliated to Ankara Metropolitan Municipality for camping purposes, after obtaining the necessary permissions. The "Sportspersonship Behavior Scale in Physical Education Course Scale" was used to measure the sportspersonship motivations of the students participating in the study, and the "Participation Motivation Questionnaire Scale" was used to measure the motivations for participation in sports. As a result of the reliability test for the scales, the Cronbach Alpha coefficient of the BEDSDÖ was found to be .86, and for the IPSAS .81. When the sportspersonship scores of the students were compared with the gender, the scores of young female students were found to be higher than the young male students, there was no difference/ relationship between the students' sportspersonship scores and the variables of class levels, parents' education levels and number of siblings. A negative, low-level, significant relationship was found between the students' sportspersonship scores and their motivation to participate in sports scores. According to this result, as the sportspersonship levels of the participants increase, their motivation to participate in sports decreases or as their sportspersonship levels decrease, their motivation to participate in sports increases.
\end{abstract}

Keywords: Sportspersonship, fair-play, motivation for participation in sports, motivation.

\footnotetext{
* Sorumlu Yazar: Şeymanur BİRCAN, E-posta: seymanurbircan@gmail.com
} 


\section{GíRiş}

Geçmişten günümüze spor; insan hayatında farklı şekil, form, kural ve kullanım amaçlarıyla yer almış, hem fiziksel olarak sağlık ve etkinlik kaynağı hem psikolojik rahatlama kaynağ1, hem de ekonomik kaygısı olan bir enstitü halini almıştır (Katkat, 2010; Tanrıverdi, 2012). Eski çağlarda beslenme ve hayatta kalma mücadelesiyle ortaya çıkan bu olgu çağlar değiştikçe farklı amaçlarda kullanılarak devam etmiş ve aynı zamanda farklı kültürlerin de etkisiyle çeşitlenerek büyümüştür (Çumralıgil ve Görücü, 2007). Spor hangi amaçla kullanılırsa kullanılsın verim elde edebilmek için spor ilke ve kurallarına, etiğine, felsefesine ve ahlakına bağlı kalmak gerekmektedir (Pehlivan, 2004) bu açıdan ele alınınca spor birçok olumlu ve olumsuz kavramı bünyesinde taşımakla beraber insan hayatını da farklı yönlerden etkilemektedir. $\mathrm{Bu}$ etkilerin ekonomik ve rekabetçi boyutu önem kazandıkça sporda sportmenlik kavramı da önemini yitirmeye ve aslında olması gereken "spor dostluk, barış ve kardeşliktir" ideali yerini "sportif hırs" a bırakmıştır (Erdemli, 1996).

Sporcuların sporda gittikçe artan sportmenlik dışı davranışlarını önlemek adına bunun tersi olan bir takım sportmence davranışlara yönlendirilmesi zorunluluk halini almıştır (Yıldıran, 2004). Bu sportmence davranışlar uluslararası ve ulusal literatürde karşımıza İngilizcedeki kullanımı olan "fair play” tabiriyle çıkmaktadır, Türkçe'de bu tabiri "adil oyun, hilesiz oyun, tarafsızlık, sportif erdem ve dürüst oyun" sözcükleri karşılamaktadır. Ayrıca Türkiye'de "fair play" kavramının ilk kez doğrudan kullanıldığı kaynak 1974 yılında Gençlik ve Spor bakanlığı tarafından M. Ateşoğlu'na tercüme ettirilen "Sportif Erdem-Fair-Play" adlı eserdir (akt. Erdemli, 1992). Sportmenlik kavramı; müsabakalar esnasında sporcuların, şartların olağanüstü güçleşmesi halinde dahi sakin, sabırlı ve tutarlı şekilde davranmaları, ne pahasına olursa olsun kendi adına haksız avantajları aynı zamanda da rakibin haksız dezavantajlarını kabul etmemeleri, rakibine dostane yaklaşmaları ve düşmanca algıdan kaçınmaları, rakibi oyunun gerçekleşmesini sağlayan bir etken olarak görmesine dayanan bir olgudur (Yıldıran, 2004). Sportmenlik kavramının vurguladığı etik prensiplere uyma sorumlulukları yalnızca sporcular için değil antrenörler, yöneticiler, taraftarlar, liderler ve aileler için de geçerlidir (Loland, 2002).

Güdülenme veya motivasyon kavramı kısaca insanı belli bir amaç doğrultusunda harekete geçiren kuvvet demektir (Baykal, 1978). Güdülenme en geniş tanımıyla insanın içinde bulunduğu psikolojik, fiziksel, biyolojik, tarihsel, ekonomik durumların etkisi altında belirli bir olguya doğru aktivite olmuşluk derecesidir (Konter,1995). Güdülenme öznel bir kavramdır çünkü insan ihtiyaç ve isteklerinden doğmuştur dolayısıyla kişiden kişiye farklılık göstermektedir, bilim insanları güdülenme ile ilgili birçok tanım yapmışlardır ve henüz yapılan tanımların güdülenme kavramını tam anlamıyla karşılamadığını savunmuşlardır (Kelecioğlu, 1992; Şirin, Çağlayan, Çetin ve İnce, 2008; Yıldırım, 2017). Dolayısıyla güdülenme, bireyi hedefleri doğrultusunda yönlendiren, arzuladığı amaçlara ulaşmaya iten, organizmayı harekete geçiren ve değişiklik yapmaya sevk eden, bireyin davranışlarında zaman zaman gözlemlenebilen kuvvettir (Konter, 1995).

Güdülenme genel olarak içe yönelik ve dişa yönelik güdülenme olarak ele alınmaktadır, içe yönelik güdülenme; kişinin kendi öznel istekleri, tatmini ve zevki gibi unsurlardır, birey içsel isteklerini doyurmaya yönelir. Dışsal güdülenme ise çevresel faktörlerden oluşmaktadır, 
toplumsal ve kültürel değerler, ceza-ödül gibi dışsal sebeplere dayanmaktadır (Weinberg ve Gould, 2015). Güdülenme kavramı içsel ve dişsal olarak bireyi hedeflere yönlendiren bir kavram olduğundan spor ortamlarında sporcuların davranışlarının açıklanmasında önemli bir yere sahiptir (Hardy, Jones ve Gould, 1997). Terzioğlu'a (1992) göre "Spor ve spor psikolojisinin temel taşı güdülenmedir”. Spor ortamlarında güdülenme kapsamlı olarak incelenmiştir, spor psikologları içsel ve dişsal motivasyon, başarı motivasyonu, yarışma stresi formundaki motivasyon gibi birçok başlık altında; motivasyonun yönü ve yoğunluğu şeklinde alt başliklarda incelemişlerdir (Weinberg ve Gould, 2015). Spor ortamlarında motivasyonu araştırırken üzerinde durulması gereken önemli noktalardan biri de başarı motivasyonudur, başarı motivasyonu Murray'a (1938) göre; "kişinin; bir görevin üstesinden gelmek, mükemmele erişmek, zorlukları aşmak, başkalarından iyi performans göstermek ve performansındaki beceriyle gurur duymak için ortaya koyduğu çabaları işaret eder". Gill'e (2000) göre ise bireyin görevini tamamlamak, başarısıyla gurur duymak ve başarısızlık karşında mücadele etme eğilimidir.

Günümüzde spor, yapılan yanlış uygulamalarla sportmenliğe aykırı davranış öğrenme ve sergileme alanına dönüştürülmüştür. $\mathrm{Bu}$ uygulamalar nedeniyle beklenilen sportmenlik davranışları önemini yitirmiş ve sporun temel prensiplerine aykırı durumlar ortaya çıkmıştır (Yıldıran, 2005). Sporda artan erdemsiz davranışların özellikle yeni yetişen genç öğrencileri tesiri altına almaması ve olması gereken etik davranışların kazandırılması için bir takım çalışmalar yapmak zorunlu hale gelmiştir. Güdülenme bireyin öznel isteklerini tatmin etmek amaciyla arzularına göre hareket etmesidir (Ohbuchi ve Suzuki, 2003), spora katılım güdülenmesi de aynı doğrultuda sporcuların kendi amaçlarını gerçekleştirmeleri için harekete geçmeleridir. Sporcuların amaçlarına ulaşmak için nasıl güdülendikleri önemli bir sorudur, güdülenirken sportif etik ve sportmen davranışların dışına çıkmamaya, sportmenlik ruhunu korumaya ve geliştirmeye çalışmaları gerekmektedir. Sporcuların sportmenlik davranışlarını etkileyen kişisel unsurlar olabileceği gibi spora katılım güdüsüyle sportmenlik davranışlarının ilişkili olabileceği düşünülmüştür. Bu varsayımdan yola çıkarak, araştırmanın amacı yaz kamplarına katılan ortaokul ve lise öğrencilerinin sportmenlik davranışları ile spora katılım güdüleri arasındaki ilişkiyi istatiksel olarak tespit etmek bunun yanında cinsiyet, sınıf düzeyi, kardeş sayısı, anne-baba eğitim durumu değişkenleriyle karşılaştırmaktır. Bu araştırmanın, gençlerin sportmenlik davranışları ile spora katılım güdüleriyle ilgili; öğretmenlerin, antrenörlerin ve ailelerinin bilgi sahibi olmasını sağlayacağı ayrıca spor psikolojisi alanına katk1 sağlayacağı düşünülmektedir. 


\section{YÖNTEM}

\section{Araştırma Modeli}

$\mathrm{Bu}$ araştırma nicel araştırma yöntemlerinden ilişkisel tarama ve kesitsel tarama yöntemiyle yapılmıştır. Büyüköztürk, Kılıç-Çakmak, Akgün, Karadeniz ve Demirel'e (2018) göre tarama modeli; hali hazırda varlığını sürdüren, devam eden olgular veya olaylara ilişkin katılımcıların görüşlerinin ya da ilgi, beceri, yetenek, tutum vb. özelliklerinin belirlendiği genellikle diğer araştırmalara göre daha büyük örneklemler üzerinde yapılan araştırmalardır. İki ya da daha fazla değişken arasındaki ilişkiyi ölçmek amacıyla yapılan araştırmalara ise ilişkisel (korelasyonel) araştırma denir.

\section{Çalışma Grubu}

Bu çalışmaya 2018 yaz döneminde Ankara Büyükşehir Belediyesi'ne bağlı Altınoluk Sosyal Tesislerine kamp amaçlı gelen 410 ortaokul ve lise öğrencisi gönüllü olarak katılmıştır. Verilerin toplanmasının ardından 19 verinin analizde kullanılamayacağı tespit edilip çıkarılmıştır, analizler 391 veriyle yapılmıştır. Katılımcılar 208 (\%53.2) genç kadın, 183 (\%46.8) erkek öğrenciden oluşmaktadır. Örnekleme alınan kamp araştırmacının iş yeri olduğundan uygun örnekleme yöntemiyle yapılmıştır. Uygun örnekleme; maddi ve manevi sınırlılıklar sebebiyle örneklemin ulaşılabilir, kolay uygulama yapılabilir birimlerden seçilmesi metodudur (Büyüköztürk vd., 2018).

\section{Veri Toplama Aracı}

Veri toplama araçları 3 bölümden oluşmaktadır. Birinci bölümde katılımcıların demografik özelliklerini tespit etmek amaciyla Kişisel Bilgi Formu, ikinci bölümde sportmenlik davranışlarını ölçmek amacıyla "Beden Eğitimi Dersi Sportmenlik Davranışı Ölçeği”, üçüncü bölümde ise spora katılım güdülerini ölçmek amacıyla "Spora Katılım Güdüsü Ölçeği”" kullanılmıştır.

Kişisel Bilgi Formu: Katılımcıların cinsiyeti, sınıf düzeyi, kardeş sayısı, anne eğitim durumu ve baba eğitim durumunu belirlemek amacıyla oluşturulmuştur.

Beden Eğitimi Dersi Sportmenlik Davranışı Ölçeği: Koç (2013) tarafından geliştirilen bu ölçek öğrencilerin beden eğitimi ve sporda sportmenlik davranışlarını ölçmek amacıyla 22 maddeden oluşturulmuş ve 5'li likert tipinde (1-hiçbir zaman, 5-her zaman), iki faktörlü; 1. Faktör, uygun davranışlar sergileme", 2. Faktör, uygunsuz davranışlardan kaçınma" olarak tasarlanmıştır. Yazar tarafından yapılan testlerle ölçek geçerli ve güvenilir bulunmuştur. Ölçekten en düşük 22 puan ve en yüksek 110 puan alınmaktadır, alınan puanlar arttıkça sportmenlik seviyesi de artmaktadır. Orijinal çalışmada toplam Cronbach Alpha katsayısı .85 hesaplanmıştır bu çalışmada ise Cronbach Alpha katsayısı .86 olarak hesaplanmıştır.

Spora Katılım Güdüsü Ölçeği: Orijinal adı "Participation Motivation Questionnaire" olan ölçek Gill ve ark. tarafından 1983'te çocuk ve gençlerin spora katılımın sebeplerini ortaya koymak amacıyla geliştirilmiştir (Akt. Oyar vd., 2001). Ölçek 30 madde, 8 alt boyut ve 3'lü ölçek tipi (1-Çok önemli, 2-Az önemli, 3-Hiç önemli değil) olarak tasarlanmıştır. Alt boyutları; Başarı/Statü, Fiziksel Uygunluk/Enerji Harcama, Takım Üyeliği/Ruhu, Arkadaş, Eğlence, Yarışma, Beceri Gelişimi, Hareket/Aktif Olma şeklindedir. Ölçek Çelebi (1993) tarafından Türkçe 'ye çevrilmiş fakat geçerlik güvenirlik çalışmaları yapılmamıştır. Geçerlik 
ve güvenirlik çalışması Oyar vd., (2001) tarafından yapılmış olup, toplam ölçek için Alpha katsayısı .86 hesaplanmıştır. Bu çalışmada Cronbach Apha Katsayısı .81 bulunmuş ve ölçeğin sadece toplam puanı alınmış, alt boyutları kullanılmamıştır.

\section{Verilerin Toplanma Süreci}

Araştırmada kullanılan ölçekler, gerekli izinler kurum tarafından alındıktan sonra öğrencilerin kamp alanındaki dinlenme saatleri takip edilerek ve özenle açıklamalar yapılarak uygulanmıştır. Katılımcılara bunun bilimsel bir araştırmanın parçası olduğu, doğru-yanlış cevap olmadığı ve kendilerini yansıtan seçenekleri işaretlemeleri gerektiği titizlikle anlatılmıştır, gönüllü olmayan öğrenciler araştırmaya dahil edilmemiştir.

\section{Verilerin Analizi}

Verilerin analizinde SPSS 22 paket programı kullanılmıştır, analizlere başlanmadan önce ölçeklerin dağılımını kontrol etmek amacıyla normallik testi yapılmıştır, verilerin normal dağılmadığı sonucuna ulaşılmış ve parametrik olmayan analizler kullanılmıştır. Öğrencilerin sportmenlik davranışları puanları ve spora katılım güdüsü puanları arasındaki ilişkiyi tespit etmek amacıyla "Spearman Brown" korelasyonu, ikili değişkenlerin karşılaştırılmasında "Mann Whitney U”, üç veya daha fazla olan değişkenlerin karşılaştırılmasında ise "Kruskal Wallis H” testleri uygulanmıştır.

\section{BULGULAR}

Araştırmanın bu bölümünde istatistiksel analizler neticesinde elde edilen verilere ilişkin bulgu ve yorumlara yer verilmiştir. Katılımcıların tanımlayıcı istatistikleri tablo 1 'de verilmiştir.

Tablo 1. Araştırmaya katılan öğrencilerin cinsiyet, sınıf, anne-baba eğitim durumuna ait dağılımları

\begin{tabular}{llcc}
\hline & Değişken & $\boldsymbol{F}$ & \% \\
\hline \multirow{4}{*}{ Cinsiyet } & Kadın & 208 & 53.2 \\
& Erkek & 183 & 46,8 \\
\hline \multirow{5}{*}{ Sinıf düzeyi } & 6. sinıf & 44 & 11.3 \\
& 7. sinıf & 90 & 23.0 \\
& 8. sinıf & 73 & 18.7 \\
& 9. sinıf & 97 & 24.8 \\
& 10. sinıf & 65 & 16.6 \\
& 11. sinıf & 6 & 1.5 \\
Anne eğitim durumu & 12. sinıf & 16 & 4.1 \\
\hline & Okur-yazar & 10 & 2.6 \\
& İlkokul & 71 & 18.5 \\
& Ortaokul & 94 & 24.5 \\
& Lise & 154 & 40.1 \\
& Üniversite & 55 & 14.3 \\
\hline & Okur-yazar & 6 & 1.6 \\
& İlkokul & 38 & 9.9 \\
& Ortaokul & 88 & 22.9 \\
Baba eğitim durumu & Lise & 161 & 41.8 \\
& Üniversite & 92 & 23.9 \\
& Toplam & $\mathbf{3 9 1}$ & $\mathbf{1 0 0}$ \\
\hline
\end{tabular}

Tablo 1'e göre araştırmaya katılan öğrencilerin \%53.2'si (n=208) genç kadın ve \%46.8'i $(\mathrm{n}=183)$ genç erkek öğrenciden oluşmaktadır. 6. sınıf öğrencilerinin \%11.3 $(\mathrm{n}=44), 7$. sinıf öğrencilerinin \%23 ( $\mathrm{n}=90), 8$. sınıf öğrencilerinin \%18.7 $(\mathrm{n}=73), 9$. sınıf öğrencilerinin $\% 24.8$ 
$(n=97), 10$. sınıf öğrencilerinin \%16.6 (n=65), 11.sınıf öğrencilerinin \%1.5 (n=6), 12. sinıf öğrencilerinin \%4.1 $(\mathrm{n}=16)$ 'den oluşmaktadır. Anne eğitim durumu; okur-yazar \%2.6 (n=10), ilkokul \%18.5 $(\mathrm{n}=71)$, ortaokul \%24.5 ( $\mathrm{n}=94)$, lise \%40.1 $(\mathrm{n}=154)$, üniversite $\% 14.3$ $(\mathrm{n}=55)$ 'den oluşmaktadır. Baba eğitim durumu; okur-yazar \%1.6 (n=6), ilkokul \%9.9 (n=38), ortaokul \%22.9 ( $\mathrm{n}=88)$, lise \%41.8 (n=161), üniversite \%23.9 (n=92)’den oluşmaktadır.

Tablo 2. Öğrencilerin sportmenlik puanlarının cinsiyete göre değişimi

\begin{tabular}{lllllll}
\hline Cinsiyet & $\boldsymbol{N}$ & $\boldsymbol{S . T}$. & $\boldsymbol{S . O}$. & $\boldsymbol{U}$ & $\boldsymbol{Z}$ & $\boldsymbol{p}$ \\
\hline Kadın & 208 & 46116.00 & 221.71 & & & \\
Erkek & 183 & 30520.00 & 166.78 & 13684.000 & -4.798 & .000 \\
Toplam & 391 & & & & \\
\hline
\end{tabular}

$* * p<0.01$

Tablo 2'de yapılan Mann Whitney U testi sonuçları genç kadın öğrenciler ve erkek öğrenciler arasında sportmenlik puanları açısından anlamlı bir fark olduğunu ortaya koymuştur. Genç kadın öğrencilerin $(\mathrm{Md}=96)$ sportmenlik puanları erkeklere $(\mathrm{Md}=90)$ göre daha yüksektir $(\mathrm{z}=-4.798, \mathrm{p}=.000)$.

Tablo 3. Öğrencilerin sportmenlik puanlarının sınıf düzeylerine göre değişimi

\begin{tabular}{|c|c|c|c|c|c|c|}
\hline & Gruplar & $N$ & S.O. & $x^{2}$ & $d f$ & $p$ \\
\hline & 6. sinıf & 43 & 213.76 & & & \\
\hline & 7. sinıf & 90 & 194.02 & & & \\
\hline Sportmenlik & 8. sinıf & 73 & 190.73 & & & \\
\hline \multirow[t]{5}{*}{ Puanları } & 9. sinıf & 97 & 194.02 & 1.824 & 6 & .935 \\
\hline & 10. sinıf & 62 & 188.23 & & & \\
\hline & 11. sinif & 6 & 187.08 & & & \\
\hline & 12. sinif & 16 & 180.56 & & & \\
\hline & Toplam & 387 & & & & \\
\hline
\end{tabular}

Tablo 3'te yapılan Kruskal Wallis H testi sonuçları öğrencilerin sportmenlik puanlarıyla sınıf düzeyleri arasında anlamlı bir farkın olmadığını ortaya koymuştur $\left(\mathrm{x}^{2}=1.824, \mathrm{p}=.935\right)$.

Tablo 4. Öğrencilerin sportmenlik puanlarının anne eğitim durumuna göre değişimi

\begin{tabular}{lllllll}
\hline & Gruplar & $\boldsymbol{N}$ & $\boldsymbol{S . O .}$ & $\boldsymbol{x}^{2}$ & $\boldsymbol{d} \boldsymbol{p}$ & \\
\hline \multirow{2}{*}{ Sportmenlik } & Okur-yazar & 10 & 138.50 & & & \\
Puanları & Ölkokul & 71 & 208.19 & & & \\
& Ortaokul & 94 & 186.34 & 4.856 & 4 & \\
& Lise & 154 & 196.57 & & \\
& Üniversite & 55 & 181.20 & & \\
& Toplam & 384 & & &
\end{tabular}

Tablo 4'te yapılan Kruskal Wallis H testi sonuçları öğrencilerin sportmenlik puanları ile anne eğitim durumları arasında anlamlı bir farkın olmadığını ortaya koymuştur $\left(x^{2}=4.856, p=\right.$ $.302)$. 
Bircan, Ş. ve Çetin, M. Ç. (2021). Yaz kamplarına katılan öğrencilerin sportmenlik davranışlarının ve spora katılım güdülerinin bazı değişkenlere göre incelenmesi. Ulusal Spor Bilimleri Dergisi, 5(1), 1-12.

Tablo 5. Öğrencilerin sportmenlik puanlarının baba eğitim durumuna göre değişimi

\begin{tabular}{lllllll}
\hline & Gruplar & $\boldsymbol{N}$ & $\boldsymbol{S . O .}$ & $\boldsymbol{x}^{2}$ & $\boldsymbol{d f}$ & $\boldsymbol{p}$ \\
\hline & Okur-yazar & 6 & 150.17 & & & \\
Silkokul & 38 & 211.97 & & & \\
Puanları & Lise & 161 & 210.98 & 5.718 & 4 & \\
& Üniversite & 92 & 183.37 & & \\
& Toplam & 385 & 187.61 & & \\
\hline$p>0.05$ & & & & &
\end{tabular}

Tablo 5'te yapılan Kruskal Wallis H testi sonuçları öğrencilerin sportmenlik puanları ile baba eğitim durumları arasında anlamlı bir farkın olmadığını ortaya koymuştur $\left(x^{2}=5.718, p=\right.$ $.221)$

Tablo 6. Öğrencilerin sportmenlik puanlarıyla kardeş sayıları arasındaki ilişki

\begin{tabular}{lccc}
\hline Değ işkenler & $\boldsymbol{N}$ & $\boldsymbol{r}$ & $\boldsymbol{p}$ \\
\hline Sportmenlik & 391 & -.033 & .523 \\
Kardeș sayısı & & & \\
\hline $\mathrm{p}>0.05$ & & &
\end{tabular}

$\mathrm{p}>0.05$

Tablo 6'da yapılan Spearman Brown korelasyonu sonuçları öğrencilerin sportmenlik puanları ile kardeş sayıları arasında anlamlı ilişki olmadığını ortaya koymuştur $(r=-.033, p=.523)$.

Tablo 7. Öğrencilerin spora katılım güdüsü puanlarının cinsiyetlerine göre değişimi

\begin{tabular}{lllllll}
\hline Cinsiyet & $\boldsymbol{N}$ & $\boldsymbol{S . T}$. & $\boldsymbol{S . O}$. & $\boldsymbol{U}$ & $\boldsymbol{Z}$ & $\boldsymbol{p}$ \\
\hline Kadın & 208 & 39496.50 & 189.89 & & & \\
Erkek & 183 & 37139.50 & 202.95 & 17760.500 & -1.142 & .253 \\
Toplam & 391 & & & & \\
\hline p $>0.05$ & & & & &
\end{tabular}

Tablo 7'de yapılan Mann Whitney U testi sonuçları öğrencilerin spora katılım güdüsü puanları ile cinsiyetleri arasında anlamlı bir farkın olmadığını ortaya koymuştur $(\mathrm{z}=-1.142$, $\mathrm{p}=.253)$.

Tablo 8.Öğrencilerin spora katılım güdüsü puanlarının sınıf düzeylerine göre değişimi

\begin{tabular}{|c|c|c|c|c|c|c|}
\hline & Gruplar & $N$ & S.O. & $x^{2}$ & $d f$ & $p$ \\
\hline & 6. sinif & 43 & 202.36 & & & \\
\hline Spora & 7. sinif & 90 & 200.23 & & & \\
\hline Katılım & 8. sinif & 73 & 182.81 & & & \\
\hline \multirow[t]{5}{*}{ Güdüsü } & 9. sinif & 97 & 191.90 & 3.729 & 6 & .713 \\
\hline & 10. sinif & 62 & 202.56 & & & \\
\hline & 11. sinif & 6 & 128.42 & & & \\
\hline & 12. sinıf & 16 & 191.69 & & & \\
\hline & Toplam & 387 & & & & \\
\hline
\end{tabular}


Bircan, Ş. ve Çetin, M. Ç. (2021). Yaz kamplarına katılan öğrencilerin sportmenlik davranışlarının ve spora katılım güdülerinin bazı değişkenlere göre incelenmesi. Ulusal Spor Bilimleri Dergisi, 5(1), 1-12.

Tablo 8'de yapılan Kruskal Wallis H testi sonuçları öğrencilerin spora katılım güdüsü puanları ile sınıf düzeyleri arasında anlamlı bir farkın olmadığını ortaya koymuştur $\left(\mathrm{x}^{2}=\right.$ $3.729, \mathrm{p}=.713)$.

Tablo 9. Öğrencilerin spora katılım güdüsü puanlarının anne eğitim durumlarına göre değişimi

\begin{tabular}{lllllll}
\hline & Gruplar & $\boldsymbol{N}$ & $\boldsymbol{S . O .}$ & $\boldsymbol{x}^{2}$ & $\boldsymbol{d f}$ & $\boldsymbol{p}$ \\
\hline \multirow{3}{*}{ Spora } & Okuryazar & 10 & 241.40 & & \\
Katılım & İlkokul & 71 & 198.17 & & & \\
Güdüsü & Ortaokul & 94 & 179.00 & 3.600 & 4 & \\
& Lise & 154 & 193.73 & & \\
& Üniversite & 55 & 195.91 & & \\
& Toplam & 384 & & &
\end{tabular}

Tablo 9'da yapılan Kruskal Wallis H testi sonuçları öğrencilerin spora katılım güdüsü puanları ile anne eğitim durumları arasında anlamlı bir farkın olmadığını ortaya koymuştur $\left(x^{2}=3.600, p=.463\right)$.

Tablo 10. Öğrencilerin spora katılım güdüsü puanlarının baba eğitim durumlarına göre değişimi

\begin{tabular}{lllllll}
\hline & Gruplar & $\boldsymbol{N}$ & $\boldsymbol{S . O}$. & $\boldsymbol{x}^{\mathbf{2}}$ & $\boldsymbol{d} \boldsymbol{f}$ & $\boldsymbol{p}$ \\
\hline \multirow{3}{*}{ Spora } & Okur-yazar & 6 & 167.25 & & & \\
Katılım & İlkokul & 38 & 205.63 & & & \\
Güdüsü & Ortaokul & 88 & 192.18 & 1.215 & 4 & \\
& Lise & 161 & 188.76 & & \\
& Üniversite & 92 & 197.66 & & \\
& Toplam & 385 & & &
\end{tabular}

Tablo 10'da yapılan Kruskal Wallis $H$ testi sonuçları öğrencilerin spora katılım güdüsü puanları ile baba eğitim durumları arasında anlamlı bir farkın olmadığını ortaya koymuştur $\left(\mathrm{x}^{2}=1.215, \mathrm{p}=.876\right)$.

Tablo 11. Öğrencilerin spora katılım güdüsü puanlarıyla kardeş sayıları arasındaki ilişki

\begin{tabular}{llll}
\hline Değişkenler & $\mathbf{N}$ & $\mathbf{R}$ & $\mathbf{p}$ \\
\hline Spora katılım güdüsü & 391 & -.011 & .832 \\
Kardeş sayısı & & & \\
\hline $\mathrm{p}>0.05$ & & &
\end{tabular}

Tablo 11'de yapılan Spearman Brown korelasyonu sonuçları öğrencilerin spora katılım güdüsü puanları ile kardeş sayıları arasında anlamlı ilişki olmadığını ortaya koymuştur ( $\mathrm{r}=-$ $.011, \mathrm{p}=.832)$. 
Bircan, Ş. ve Çetin, M. Ç. (2021). Yaz kamplarına katılan öğrencilerin sportmenlik davranışlarının ve spora katılım güdülerinin bazı değişkenlere göre incelenmesi. Ulusal Spor Bilimleri Dergisi, 5(1), 1-12.

Tablo 12. Öğrencilerin sportmenlik puanlarıyla spora katılım güdüsü puanları arasındaki ilişki

\begin{tabular}{lccc}
\hline Değişkenler & $\mathbf{N}$ & $\mathbf{R}$ & $\mathbf{p}$ \\
\hline Sportmenlik & 391 & -.179 & .000 \\
Spora katılım güdüsü & & &
\end{tabular}

Tablo 12'de yapılan Spearman Brown korelasyonu sonuçları öğrencilerin sportmenlik puanları ile spora katılım güdüsü puanları arasında negatif yönde anlamlı bir ilişki olduğunu ortaya koymuştur $(\mathrm{r}=-.179, \mathrm{p}=.000)$.

\section{TARTIŞMA VE SONUÇ}

$\mathrm{Bu}$ araştırmanın ilk amacı doğrultusunda yaz kamplarına katılan öğrencilerinin sportmenlik davranışlarıyla spora katılım güdüleri arasındaki ilişki incelenmiş, alt amaçları doğrultusunda ise öğrencilerin sportmenlik puanları ve spora katılım güdüsü puanları; cinsiyet, sınıf düzeyi, kardeş sayısı, anne eğitim durumu ve baba eğitim durumu değişkenleriyle karşılaştırılmıştır.

Araştırmanın ilk amacı doğrultusunda yapılan korelasyon analizi öğrencilerin sportmenlik puanları ve spora katılım güdüsü puanları arasında negatif yönde düşük düzeyde anlamlı ilişki bulunduğunu ortaya koymuştur. Öğrencilerin sportmenlik puanları ile cinsiyetlerinin karşılaştırılması sonucunda genç kadın öğrencilerin sportmenlik puanlarının erkeklere göre daha yüksek olduğu sonucu ortaya çıkmıştır. Bu sonuç genç kadın öğrencilerin sporda etik davranışlara erkeklere göre daha fazla önem verdiğini göstermektedir, diğer bir değişle cinsiyetin sportmenlik davranışını etkilediği ortaya konmuştur. Alanda yapılan diğer çalışmalar incelendiğinde; çalışmaların bazılarının bu sonuçla paralel olduğu (Esentürk, İlhan ve Çelik, 2015; Gümüş, Saraçlı, Karakullukçu, Doğanay ve Kurtipek, 2016; Koç ve Güllü, 2017; Tsai ve Fung, 2005), bazı çalışmaların sonuçlarında ise cinsiyetin sportmenlik davranışını etkilemediği (Kayışoğlu, Altınkök, Temel ve Yüksel, 2015; Miller, Roberts ve Ommundsen, 2004) bulunmuştur. Öğrencilerin sportmenlik puanları ile sınıf düzeylerinin karşılaştırılması sonucunda anlamlı bir fark bulunamamıştır. Alan yazın incelendiğinde Kayışoğlu vd., (2015) ve Efe (2016)'nin çalışmalarında da öğrencilerin sınıf düzeyi ve sportmenlik davranışları arasında anlamlı bir fark bulunmadığı görülmüştür. Esentürk vd., (2015) ise 15 yaşındaki öğrencilerin 16 ve 17 yaşlarındaki öğrencilere göre sportmenlik puanlarının yüksek olduğu sonucuna ulaşmıştır. Öğrencilerin sportmenlik puanları ile annebaba eğitim durumları ayrı değişkenler olarak incelenmiş her iki tabloda da anlamlı bir fark bulanamamıştır. Alan yazında ebeveynlerin eğitim durumu değişkeniyle ilgili karşılaştırma yapılacak çalışmalara rastlanmamıştır. Öğrencilerin sportmenlik puanlarıyla kardeş sayıları arasında anlamlı bir ilişki bulunamamıştır, alan yazında bu değişkenlerle ilgili karşılaştırma yapılacak çalışmalara rastlanmamıştır.

Öğrencilerin spora katılım güdüsü puanlarıyla cinsiyetlerinin karşılaştırılması sonucunda anlamlı bir fark bulunamamıştır. Karaç (2017) hazırlamış olduğu doktora tez çalışmasında bu sonuçla paralel bir sonuca ulaşmıştır, literatürdeki diğer çalışmalar incelendiğinde genellikle ölçeğin alt boyutları açısından cinsiyette farklılıklar bulunmuştur. Sirard, Pfeiffer ve Pate'nin (2006), ortaokulda yaptıkları bir çalışma genç kadınların genellikle sosyal sebeplerle 
erkeklerin ise genellikle rekabetçi sebeplerle güdülendiklerini ortaya koymuştur. Yapılan araştırmaların sonucunda erkeklerle kadınların güdülenmelerinde farklılıklar olabileceği gibi benzerlikler de bulunmuştur. Öğrencilerin spora katılım güdüsü puanlarıyla sınıf düzeylerinin karşılaştırılması sonucunda anlamlı bir fark bulunmamıştır. Şirin (2008) ortaokul öğrencileriyle yapmış olduğu araştırmada bu çalışma sonucuyla paralel bir sonuç elde etmiştir. Alanda yapılan diğer çalışmalar incelendiğinde ise çocuk ve genç öğrencilerin spora katılım güdülerinin alt boyutları açısından spora katılım nedenleri farklılıklar göstermektedir. Örneğin; Gill ve Williams'ın (2008) yaptıkları bir çalışmada çocukların, beceri gelişimi, yetenek gösterme, mücadele, heyecan ve eğlence gibi sebeplerden güdülendikleri ortaya koyulmuştur. Wankel 1980 'de yaptığı bir araştırmada ise yetişkinlerin sağlık, kilo alıpverme, fiziksel uygunluk, kendi kendinle mücadele gibi sebeplerden ötürü spora katılımda güdülendikleri sonucunu ortaya koymuştur. Öğrencilerin spora katılım güdüsü puanları ile anne-baba eğitim durumları ayrı değişkenler olarak incelenmiş her iki tabloda da anlamlı bir fark bulanamamıştır. Literatür incelendiğinde karşılaş̧ırılacak çalışmaya rastlanmamıştır. Öğrencilerin spora katılım güdüsü puanlarıyla kardeş sayıları arasında anlamlı bir ilişki bulunamamıştır alan yazında bu değişkenlerle ilgili karşılaştırma yapılacak çalışmalara rastlanmamıştır.

Sonuç olarak ortaokul ve lise öğrencileri üzerinde yapılan bu araştırmada öğrencilerin sportmenlik puanları ve spora katılım güdüleri arasında olumsuz yönde bir ilişki saptanmış bu iki değişkenden birinin gücü arttıkça diğerinin gücünün azaldığı ortaya konmuştur. Başka bir değişle öğrencilerin sportmenlik puanları arttıkça spora katılım güdüleri düşmekte veya sportmenlik puanları düştükçe spora katılım güdüleri artmaktadır.

Literatür incelendiğinde sportmenlik ve spora katılım güdüsü kavramlarının genellikle benzer değişkenlerle karşılaştırıldığı görülmektedir. Bu denli araştırmalar yapılırken değişken olarak katılımcıların çevresel, sosyal, kültürel, sosyo-ekonomik, ailesel özellikleri baz alınırsa daha fazla katk1 sağlanacağ d düşünülmektedir. Ayrıca Türkiye'deki 7 bölgenin birbirinden farklı özellikleri de dikkate alınıp ülke genelinde kapsamlı bir çalışma yapılması önerilebilir.

Yayın Etiği: Bu çalışmanın hazırlanma ve yazım sürecinde "Yükseköğretim Kurumları Bilimsel Araşstrma ve Yayın Etiği Yönergesi" kapsamında bilimsel, etik ve alıntı kurallarına uyulmuş olup; toplanan veriler üzerinde herhangi bir tahrifat yapılmamış ve bu çalışma herhangi başka bir akademik yayın ortamına değerlendirme için gönderilmemiştir.

Çıkar Çatışması: Yazarlar arasında herhangi bir çıkar çatışması yoktur.

Araştırmacıların Katkı Oranı Beyanı: 1. Yazarın \%60, 2.yazarın \%40 katkısı bulunmaktadır. 
Bircan, Ş. ve Çetin, M. Ç. (2021). Yaz kamplarına katılan öğrencilerin sportmenlik davranışlarının ve spora katılım güdülerinin bazı değişkenlere göre incelenmesi. Ulusal Spor Bilimleri Dergisi, 5(1), 1-12.

\section{KAYNAKLAR}

Baykal, B. (1978). Motivasyon kavramına genel bir bakış işyerinde motivasyon. İstanbul: İstanbul Üniversitesi Yayınevi.

Büyüköztürk, Ş., Kılıç Çakmak, E., Akgün, Ö. E., Karadeniz, Ş. ve Demirel, F. (2018). Eğitimde bilimsel araştırma yöntemleri (25). Ankara: Pegem Akademi Yayınları.

Çumralıgil, B. ve Görücü, A. (2007). Örgütlenme yönetim biçimleriyle spor. Konya: Selçuk Üniversitesi Yayını.

Efe, Z. B. (2006). Okullar arası yarışmalara katılan 1. ve 2. kademe ilköğretim öğrencilerinin fair play davranışlarını sergileme sıklıkları (Yayımlanmamış yüksek lisans tezi). Gazi Üniversitesi Eğitim Bilimleri Enstitüsü, Ankara.

Erdemli, A. (1992). Fair play ve olimpizm, Spor Bilimleri II. Ulusal Kongresi Bildirileri (20-22 Kasım 1992, Hacettepe Üniversitesi, Ankara). Spor Bilimleri ve Teknolojisi Yay, Ankara: Onlar Ajans, 180.

Erdemli, A. (1996). Insan, spor ve olimpizm. İstanbul: Sarmal Yayınevi, 151.

Esentürk, O. K., İlhan, E. L. \& Çelik, O. B. (2015). Examination Of High School Students' Sportsmanlike Conducts In Physical Education Lessons According To Some Variability. Science Movement and Health, 15 (2), 627-634.

Gill, D. (2000). Psychological dynamics of sport and exercise. Champaign, IL: Human Kinetics.

Gill, D. \& Williams, L. (2008). Psychological dynamics of sport and exercise (3rd ed.). Champaign, IL: Human Kinetics.

Gümüş, H., Saraçlı, S., Karakullukçu, Ö.F., Doğanay, G. ve Kurtipek, S. (2016). Orta Öğretim öğrencilerinde fair play kavramı. International Journal of Science Culture and Sport, 4 (2), 430-438.

Hardy, L., Jones, G. \& Gould, D., (1997). Understanding psychological preparation for sport: theory and practice of elite performers. Chichester, West Sussex: John Wiley and Sons, 72-80.

Karaç, Y. (2017). Sporcu eğitim merkezlerindeki atletizm branşı öğrenci-sporcuların başarı algıları ile spora katılım güdülerinin incelenmesi (Yayımlanmamış doktora tezi). Hitit Üniversitesi Sosyal Bilimler Enstitüsü, Çorum.

Katkat, D. (2010). Türk yazılı spor basınında futbol ve fair play. Beden Eğitimi ve Spor Bilimleri Dergisi, 7 (3), 0-0. https://dergipark.org.tr/tr/pub/ataunibesyo/issue/28866/308780

Kayışoğlu, N. B., Altınkök, M., Temel, C. ve Yüksel, Y. (2015). Ortaokul Öğrencilerinin Beden Eğitimi Dersi Sportmenlik Davranışlarının İncelenmesi: Karabük İli Örneği. International Journal of Social Sciences and Education Research, 1 (3), 865-874.

Kelecioğlu, H. (1992). Güdülenme. Hacettepe Üniversitesi Ĕ̆itim Fakültesi Dergisi, 7, 175-181.

Koç, Y. (2013). Beden Eğitimi Dersi Sportmenlik Davranışı Ölçeği (BEDSDÖ): Geçerlik ve Güvenirlik Çalışması. Erzincan Üniversitesi Eğitim Fakültesi Dergisi, $15 \quad$ (1), 96-114. https://doi.org/.10.17556/erzief.319393

Koç, Y. ve Güllü, M. (2017). Lise öğrencilerinin beden eğitimi dersi sportmenlik davranışlarının bazı değişkenlere göre incelenmesi. Spormetre Beden Eğitimi ve Spor Bilimleri Dergisi, 15 (1), 19-30. https://doi.org/10.1501/Sporm_0000000304

Konter, E. (1995). Sporda motivasyon. İzmir: Saray Medikal Yayıncılık.

Loland, S. (2002). Fair play in sport: A moral norm system. London: Routledge.

Miller, B.W., Roberts, G.C. \& Ommundsen, Y. (2004). Effect of motivational climate on sportspersonship among competitive youth male and female football players. Scandinavian Journal of Medicine \& Science in Sport, 14, 193-202. 
Bircan, Ş. ve Çetin, M. Ç. (2021). Yaz kamplarına katılan öğrencilerin sportmenlik davranışlarının ve spora katılım güdülerinin bazı değişkenlere göre incelenmesi. Ulusal Spor Bilimleri Dergisi, 5(1), 1-12.

Murray, H.A. (1938). Explorations in personality. New York: Oxford Universty Press.

Ohbuchi, K. \& Suzuki, M. (2003). Three Dimensions of Conflict Issuesand Their Effects on ResolutionStrategies in OrganizationalSettings, International Journal of Organizational Management, 14 (1), 61-73.

Oyar, Z.B., Aşçı, F.H., Çelebi, M. ve Mülazımoğlu, Ö. (2001). Spora Katılım Güdüsü Ölçeği’nin geçerlik ve güvenirlik çalışması. Hacettepe Spor Bilimleri Dergisi, 12 (2), 21-32.

Pehlivan, Z. (2004). Fair-Play kavramının geliştirilmesinde okul sporunun yeri ve önemi. Spormetre Beden Eğitimi ve Spor Dergisi, 2 (2), 49-53.

Sirard, J. R., Pfeiffer, K. A. \& Pate, R. R. (2006). Motivational factors associated with sports program participation in middle school children. Journal of Adolescent Health, 38, 696-703.

Şirin, E. F. (2008). Futbolcu kızların (12-15 yaş) spora katılım motivasyonlarının belirlenmesi. Spormetre Beden Eğitimi ve Spor Bilimleri Dergisi, 6 (1), 1-7.

Şirin, E. F., Çağlayan, H. S., Çetin, M. Ç. ve İnce, A. (2008). Spor yapan lise öğrencilerinin spora katılım motivasyonlarına etki eden faktörlerin belirlenmesi. Niğde Üniversitesi Beden Eğitimi ve Spor Bilimleri Dergisi, 2 (2), 98-110.

Tanrıverdi, H. (2012). Spor ahlakı ve şiddet. The Journal of Academic Social Science Studies, 5 (8), 1071-1093.

Terzioğlu, A. E. (1992). Spor eğitiminde motivasyon kavramı. Atatürk Eğitim Fakültesi Spor Bilimleri Dergisi, $102,11-13$.

Tsai, E., \& Fung, L. (2005). Sportspersonship in youth basketball and volleyball players. The Online Journal of Sport Psychology, 7 (2), 17.

Wankel, L. M. (1980). Involvement in vigorous physical activity: Considerations for enhancing self-motivation. In R. R. Danielson \& K. F. Danielson (Eds), Fitness motivation: Proceedings of the Geneva Park workshop, 18-32.

Weinberg, R. S. \& Gould, D. (2015). Spor ve egzersiz psikolojisinin temelleri (6). (M. Şahin ve Z. Koruç, Çev. $E d$.$) . Ankara: Anı Yayıncılık.$

Yıldıran, İ. (2004). Fair play kapsamı, Türkiye'deki görünümü ve geliştirme perspektifleri. Gazi Beden Ĕ̌gitimi ve Spor Bilimleri Dergisi, 9 (4), 3-16.

Yıldıran, İ. (2005). Fair play eğitiminde beden eğitiminin rolü. Gazi Beden Eğitimi ve Spor Bilimleri Dergisi, 10 (1), 3-16.

Yıldırım, M. (2017). Üniversite takımlarında mücadele eden sporcuların spora katılım motivasyonlarına etki eden faktörlerin belirlenmesi (Eskişehir Osmangazi Üniversitesi Örneği). Eskişehir Osmangazi Üniversitesi Sosyal Bilimler Dergisi, 18(1), 41-51.

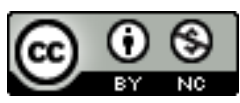

Bu eser Creative Commons Atıf-Gayri Ticari 4.0 Uluslararası Lisansı ile lisanslanmıştır. 